\title{
Functionality, school participation and quality of life of schoolchildren with cerebral palsy
}

\section{Funcionalidade, participação escolar e qualidade de vida de escolares com paralisia cerebral}

\author{
Afonso Rodrigues Tavares Netto ${ }^{[}\left[{ }^{[a]}\right.$, Carine Carolina Wiesiolek ${ }^{[a]}$, Patrícia Meireles Brito (iD [a]

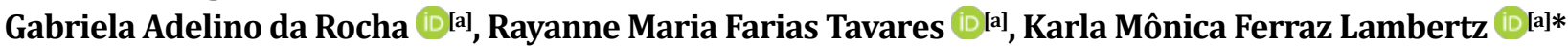

[a] Universidade Federal de Pernambuco (UFPE), Recife, PE, Brazil

\begin{abstract}
Introduction: The quality of life (QoL) of schoolchildren with cerebral palsy (CP) should be evaluated considering the functional variability of the child with CP with an extended view on functionality in the school context and the determinants of QoL. Objective: to evaluate the school participation and the QoL of schoolchildren with CP in Recife's municipal public network, as well as to analyze the influence of GMFCS levels and motor performance on these variables in the study population. Method: This is an exploratory observational study whose evaluation model was structured based on the International Classification of Functioning, Disability and Health (CIF). Children with CP were classified in the Gross Motor Function Classification System (GMFCS) and evaluated according to Gross Motor Function Measure-88 (GMFM-88). The School Function Assessment (SFA) and the Quality of Life Questionnaire for Cerebral Palsy (CPQOL-Caregiver) were answered by teachers and mothers, respectively. Results: In the study population, the higher the GMFCS level, the lower the participation and the lower the independence in school activities, aspects that add to the QoL
\end{abstract}

*ARTN: MS, e-mail: afonso.tavares.jp@gmail.com CCW: PhD, e-mail: carinecwi@gmail.com

PMB: Doctoral Student, e-mail: meireles.patricia@hotmail.com

GAR: BS, e-mail: gabiadrocha@gmail.com

RMFT: BS, e-mail: rayanna.farias.tavares@gmail.com

KMFL: PhD, e-mail: karla_monica@hotmail.com 
construct, mainly with less functionality, less emotional well-being and self-esteem, and lower family health. Conclusion: GMFCS levels and motor performance of schoolchildren with CP can affect school participation and QoL, and it is important to consider each child's individual and contextual factors. These results can help the development of functional, care, inclusion and pedagogical strategies for students with CP.

Keywords: International Classification of Functionality, Disability and Health. Special Education. Disabled Children. School Health Services.

\title{
Resumo
}

\begin{abstract}
Introdução: A qualidade de vida (QV) do escolar com paralisia cerebral (PC) deve ser avaliada considerando a variabilidade funcional da criança com PC com olhar ampliado sobre a funcionalidade no contexto escolar e os determinantes da QV. Objetivo: avaliar a participação escolar e a QV de escolares com PC da rede pública municipal do Recife, bem como analisar a influência dos níveis do GMFCS e do desempenho motor sobre essas variáveis na população estudada. Método: Trata-se de um estudo observacional exploratório cujo modelo de avaliação foi estruturado com base na Classificação Internacional de Funcionalidade, Incapacidade e Saúde (CIF). As crianças com PC foram classificadas no Sistema de Classificação da Função Motora Grossa (GMFCS) e avaliadas segundo o Gross Motor Function Measure-88 (GMFM-88). O School Function Assessment (SFA) e o Questionário de Qualidade de Vida da Paralisia Cerebral (CPQOL-Cuidador) foram respondidos por professores e mães, respectivamente. Resultados: Na população estudada, quanto maior o nível do GMFCS, menor a participação e menor a independência nas atividades escolares, aspectos que se somam ao constructo de QV, principalmente, com a menor funcionalidade, o menor bem-estar emocional e autoestima e a menor saúde familiar. Conclusão: Os níveis de GMFCS e o desempenho motor de escolares com PC podem repercutir na participação escolar e na QV, sendo importante considerar fatores individuais e contextuais de cada criança. Esses resultados podem auxiliar o desenvolvimento de estratégias funcionais, assistenciais, inclusivas e pedagógicas aos escolares com PC.
\end{abstract}

Palavras-chave: Classificação Internacional de Funcionalidade, Incapacidade e Saúde. Educação Especial. Criança com Deficiência. Serviços de Saúde Escolar.

\section{Introduction}

The biomedical model for understanding disability, restricted to injury and the need for corporate care, confronts the social model of difficulty based on social inclusion and oppression suffered by the person with a disability [1]. The biopsychosocial understanding of the health of people with disabilities was enhanced by the vision of human functionality brought by the International Classification of Functionality, Disability and Health (ICF) that conceptualizes it based on the interaction model of health condition, corporate aspects, performance in activities and social participation, considering environmental and personal factors [2].

In the life cycle of children with Cerebral Palsy (CP), the school can be considered an important space for social participation. School indicators for 2018 point to an increase of $33.2 \%$ in the enrollments of special education in the Brazilian school network, however, the census surveys do not consider the information on school inclusion of children with disabilities, this way indicating the need for studies related to this population $[3,4]$.

Studies that evaluated the level of gross motor function and the school participation of children with CP point out a worsening in the performance of school activities and greater restrictions in school participation in children with higher levels of the Gross Motor Function Classification System (GMFCS) [5-9]. However, these studies lack strategies for evaluating the functionality of the student with CP that consider the functional variability of the child with CP and that broaden the view 
on functionality, disability, contextual factors and the determinants of Quality of Life (QoL) of this population.

In view of the need for studies that analyze the functionality, school participation and QoL of schoolchildren with $\mathrm{CP}$ and considering the national fragility of census data on children with $\mathrm{CP}$, this study sought to assess school participation and QoL of schoolchildren with $\mathrm{CP}$ in the network of municipal public health of Recife, as well as to analyze the influence of GMFCS levels and motor performance on these variables in the studied population.

\section{Method}

The study was carried out in the public network of Recife (in Pernambuco state (PE)), Brazil, between August 2018 and March 2019, having a descriptive observational character considering data from students with CP, so that teachers and mothers were also accessed to collect information. The age range of 5 to 10 years was defined because it is common to the application of the assessment instruments used and because it precedes the appearance of the physiological effects of adolescence [10].
Students with CP were identified by providing data from the Secretaria de Educação do Recife via Setor de Informações e Ordenamento do Recife, indicating 374 students with physical disabilities in the network in 2018, including 147 children with physical disabilities from 5 to 10 years old. It was necessary for the responsible researcher to access the schools, by means of visits and telephone contacts to check the medical reports proving the $\mathrm{CP}$, established by the International Classification of Disease (ICD) G80.

Students with CP who had associated diagnoses (severe orthopedic changes, neuromuscular diseases, cardiorespiratory decompensation) or severe cognitive changes that limited the application of the motor performance analysis instrument were excluded from the study. For this, medical reports and opinions issued by the pedagogical team were considered.

The collections were carried out at night, with the child, the legal guardian and the teacher who accompanies the child most of the time in the school routine. The procedures were performed by a trained researcher, in a previously prepared school environment, in a reserved space, allowing free mobility of the child, who used light clothes, according to the rules of the instruments application manuals.

The evaluation of students with CP followed the ICF model shown in Figure 1.

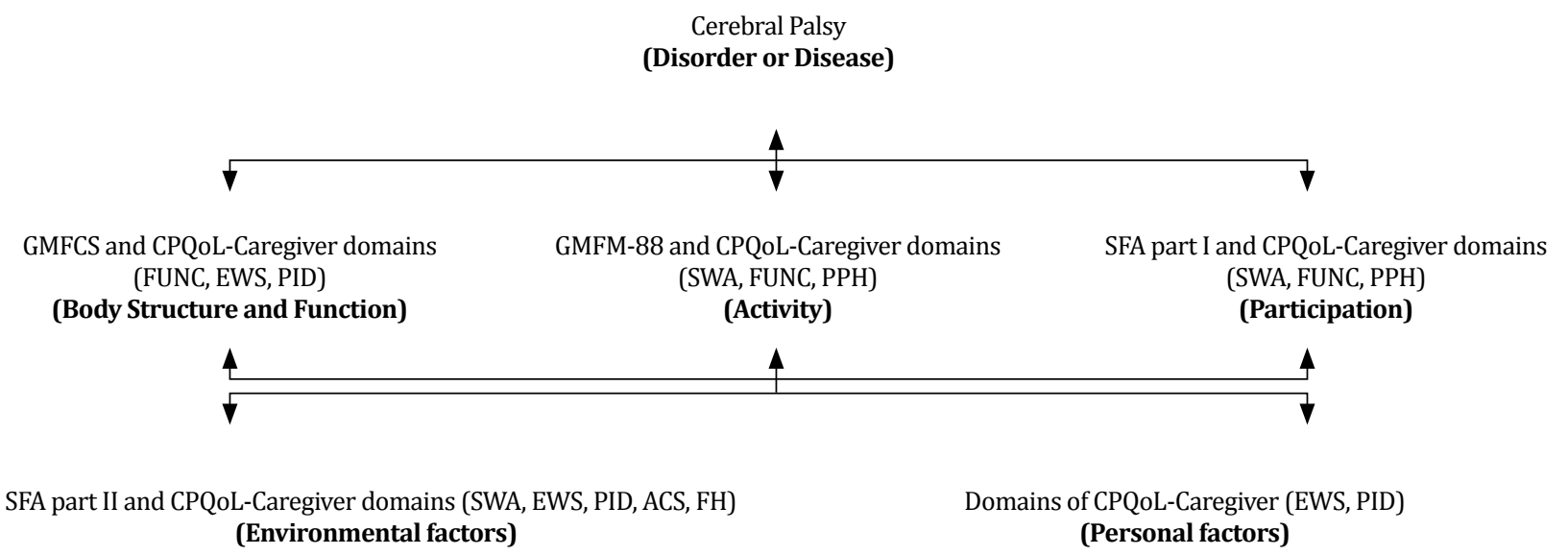

Figure $\mathbf{l}$ - Proposal for evaluating the functionality of students with CP.

Initially, the students were classified according to the functional level by the GMFCS, an instrument already adapted for the Brazilian population [11], which stratifies the child with CP at the following levels: I - without limitations for walking; II - wanders with limitations; III - walking with the use of manual mobility resources;
VI - self-mobility with limitations, being able to use a motorized chair; and V - transported in adapted wheelchairs $[12,13]$.

The evaluation of motor performance was performed using the Gross Motor Function Measure-88 (GMFM-88), a scale used as an observational measure that verifies the 
performance and quality of movement in a controlled environment, targeted at the age group from 5 months to 16 years [14]. This instrument has five (5) dimensions that measure scores between 0 (does not start the movement) to 3 (starts the movement). The sum of the scores of the items of the dimensions generates total scores in gross values, which can be converted into percentiles. The total score can be generated from the average of the total percentage score for each dimension.

Participation and the degree of independence in school activities were assessed using the School Functional Assessment (SFA), an instrument divided into three parts (participation, help with tasks and performance) which, although not validated for Brazilian children, American studies support in its validity and reliability $[15,16]$. The gross SFA scores allowed to quantify, respectively, the variable of participation (part I) and independence in school activities (part II), so that higher scores indicate greater participation and independence of the child in school activities.

Part I of the SFA allows quantifying the child's participation in seven school environments (regular or special class, playground, transportation, bathroom, transitions and meal times) with scores from 1 to 6 , indicating from "extremely limited participation" in score 1, to "total participation" in score 6.

Part II concerns assistance with physical tasks, optional tasks (climbing/descending stairs, written work, use of computers and equipment) and cognitive/ behavioral tasks quantified in terms of the level of assistance and adaptation offered for their performance. The scores are presented as: 1 . extensive assistance/ adaptation; 2 . moderate assistance/adaptation; 3 . minimal assistance/adaptation; 4 . no assistance/adaptation.

To assess the QoL of students with CP, the Cerebral Palsy Quality of Life Questionnaire (CPQoL) was used in the version answered by the caregiver (CPQoLCaregiver). This instrument has seven domains: Social Welfare and Acceptance (SWA); Functionality (FUNC); Participation and Physical Health (PPH); Emotional Well-Being and Self-Esteem (EWS); Access to Services (ACS); Pain and Impact of Disability (PID); and Family Health (FH). It was developed by international experts $[17,18]$ and allows the choice of scores from 1 (very sad) to 9 (very happy), already adapted for the Brazilian population [19], whose analysis can be done by means of scores converted into scale from 0 to 100 , according to the instrument's manual [20]. In the present study, CPQoL-Caregiver was used, considering the fact that the children's mothers were primary caregivers of the evaluated students.

The evaluation questionnaire of the Associação Brasileira de Empresas e Pesquisas (ABEP) was used to collect socioeconomic information, answered by the children's mothers. This instrument uses national criteria for economic classification which stratifies into descending classes A, B1, B2, C1, C2, D-E [21].

For the statistical analysis of the data, the software Statistical Package for the Social Science version 20.0 was used. Qualitative variables were described in absolute frequency and percentile, and quantitative variables by means of standard and standard deviation. Soon after, the Shapiro-Wilk test was performed to verify the normality of the data, being identified the quantitative variables of normal distribution (scores of part I of the SFA and of the domains of CPQoL-Caregiver) and nonparametric distribution (scores Part II of the SFA and GMFM-88). The $t$ test of a sample for intra-level comparison of GMFCS and QoL domains was used.

The Spearman correlation test $(\rho)$ was used to correlate the total scores of parts I and II of the SFA and of the CPQoL-Caregiver domains with the GMFCS levels and the gross scores of the GMFM-88. Therefore, the correlations were considered weak if ${ }^{\prime}=0.3|\rho|<0.5^{\prime}$; moderate, if $^{\prime}=0.5|\rho|<0.7$; ; and strong if $|\rho| \geq 0.7$ ', positive if directly proportional and negative if inversely proportional, using $\mathrm{p}<0.05$ as the level of significance [22].

To identify whether there were differences in QoL, participation and school independence according to the classification of children's motor function, the sample was stratified into groups by the GMFCS. The KruskalWallis test was used with the Man-Whitney post-hoc test for part II of the SFA and the One-Way Analysis of Variance (ANOVA) test with Tukey's post-hoc test for part I of the SFA and for the CPQoL-Caregiver domains, also considering the level of significance $\mathrm{p}<0.05$.

The study followed the rules of Resolution 466/2012 of Conselho Nacional de Ética em Pesquisa (CONEP), submitted to the Comitê de Ética em Pesquisa do Centro de Ciências da Saúde (CCS) of Universidade Federal de Pernambuco (UFPE), under CAAE 92234618.0.0000.5208, with opinion approval number 2,891,749. All teachers and mothers of schoolchildren with $\mathrm{CP}$ were instructed on the importance of research, its risks and benefits, prior to signing the Free and Informed Consent Terms (ICFs), agreeing to participate in the study, so that, in return, informative folders and guidance on care and handling for schoolchildren with $\mathrm{CP}$ were distributed. 
Total schoolchildren with physical disabilities 5-10 years: 147

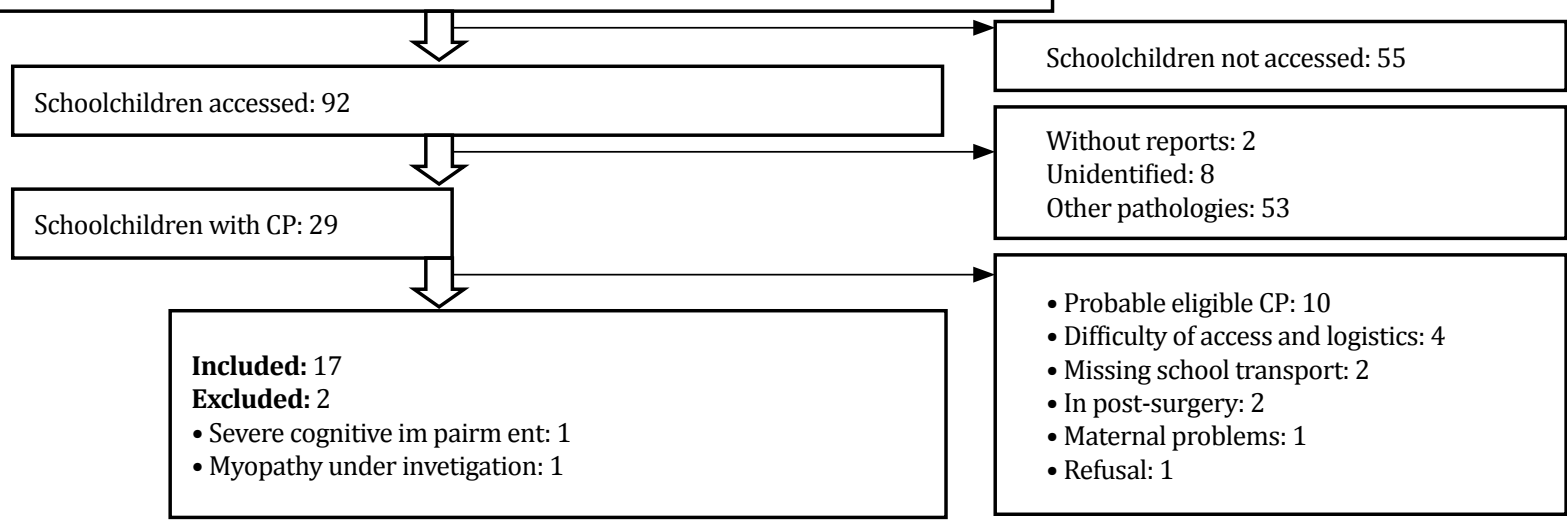

Figure 2 - Sample characteristics and total weight score of the GMFM- $88^{1}$ of children with Cerebral Palsy (CP) enrolled in public schools in the municipal network of Recife - PE/Brazil, 2019.

\section{Results}

After an active search in 81 schools and data collection from 92 children, 17 students with CP were included in the study, as shown in Figure 2.

Five children $(29.4 \%)$ were classified in GMFCS I, five $(29.4 \%)$ in GMFCS II, four $(23.5 \%)$ in GMFCS IV and three $(17.6 \%)$ in GMFCS V. There were eleven $(64.7 \%)$ male and six (35.2\%) female, with a mean age of $8.1 \pm 1.8$ years, with ten (58.8\%) students with $\mathrm{CP}$ classified in the economic classes D and $\mathrm{E}$ of ABEP. Table 1 presents the descriptive characteristics of the children evaluated, making it possible to identify lower total gross scores and weight averages of the GMFM-88 in children with CP classified in GMFCS IV and V.

Table 1 - Sample characteristics and total weight score of the GMFM- $88^{1}$ of children with Cerebral Palsy (CP) enrolled in public schools in the municipal network of Recife - PE/Brazil, 2019

\begin{tabular}{|c|c|c|c|c|c|c|}
\hline Child* & Gender & Age (years) & GMFCS $^{1}$ & $\begin{array}{l}\text { Topographic } \\
\text { Distribution }\end{array}$ & GMFM- $88^{2}$ & $\mathrm{ABEP}^{3}$ class \\
\hline 1 & Female & 9 & IV & Quadriplegia & $17.9 \%$ & $D-E$ \\
\hline 2 & Female & 9 & $\|$ & Diplegia & $88.91 \%$ & $D-E$ \\
\hline 3 & Male & 9 & $\|$ & Hemiplegia $\mathrm{E}$ & $85.75 \%$ & $\mathrm{C} 1$ \\
\hline 4 & Female & 5 & I & Hemiplegia $\mathrm{E}$ & $93.44 \%$ & $D-E$ \\
\hline 5 & Male & 9 & IV & Diplegia & $30.12 \%$ & D-E \\
\hline 6 & Female & 7 & 1 & Hemiplegia $\mathrm{E}$ & $96.55 \%$ & $D-E$ \\
\hline 7 & Male & 10 & IV & Diplegia & $12.58 \%$ & C2 \\
\hline 8 & Male & 10 & 1 & Hemiplegia $\mathrm{E}$ & $96.55 \%$ & B2 \\
\hline 9 & Female & 7 & I & Hemiplegia D & $96.55 \%$ & $D-E$ \\
\hline 10 & Male & 10 & IV & Quadriplegia & $12.58 \%$ & $\mathrm{C} 2$ \\
\hline 11 & Male & 8 & 1 & Hemiplegia D & $97.35 \%$ & $\mathrm{C} 2$ \\
\hline 12 & Male & 10 & V & Quadriplegia & $16.62 \%$ & $\mathrm{C} 2$ \\
\hline 13 & Male & 7 & IV & Diplegia & $35.08 \%$ & $D-E$ \\
\hline 14 & Male & 6 & V & Quadriplegia & $11.32 \%$ & $D-E$ \\
\hline 15 & Male & 10 & V & Quadriplegia & $1.56 \%$ & $D-E$ \\
\hline 16 & Female & 10 & $\|$ & Hemiplegia $\mathrm{E}$ & $93.46 \%$ & $D-E$ \\
\hline 17 & Male & 8 & $\|$ & Diplegia & $76.09 \%$ & C1 \\
\hline
\end{tabular}

Note: Source: Research Data, 2019. Caption: ${ }^{1}=$ Gross Motor Function Classification System; ${ }^{2}=$ Gross Motor Function Measure-88; $3=$ Socioeconomic classes of the Brazilian Association of Research Companies. 
As for school aspects, shown in Table 2, significant differences were observed in school participation between children with CP from GMFCS I with those from GMFCS IV $(p=0.007)$ and V $(p=0.002)$, as well as between children classified in GMFCS II with those of GMFCS IV ( $p=0.022)$ and V ( $p=0.007)$. Regarding assistance in school tasks, a significant difference was found between children with $\mathrm{CP}$ classified in GMFCS I with GMFCS IV ( $\mathrm{p}=0.043)$ and GMFCS V ( $\mathrm{p}=0.001)$, as well as in those of GMFCS II with those of GMFCS IV ( $\mathrm{p}=0.011$ ) and GMFCS V $(\mathrm{p}=0.001)$, with a strong negative correlation for school participation $(\mathrm{p}<0.01, \rho=-0.818)$ and help with tasks $(\mathrm{p}<0.01, \rho=-0.721)$.

Table 2 - Means, standard deviation, differences between GMFCS levels and the relationship between SFA and CPQoL-Caregiver variables by GMFCS level of students with Cerebral Palsy (CP) in the municipal public school system in Recife, Brazil, 2019

\begin{tabular}{|c|c|c|c|c|c|c|c|}
\hline \multicolumn{8}{|c|}{ GMFCS } \\
\hline \multicolumn{2}{|c|}{ Outcomes } & I & II & IV & v & $\begin{array}{l}\text { ANOVA } \\
\text { one-way } \\
p \text { value }\end{array}$ & $\begin{array}{l}\text { Spearman's } \\
\text { coefficient ( } \rho \text { ) }\end{array}$ \\
\hline \multirow{3}{*}{$\begin{array}{l}\text { Parts of the } \\
\text { SFA }\end{array}$} & & Mean $( \pm S D)$ & Mean $( \pm S D)$ & Mean $( \pm S D)$ & Mean $( \pm S D)$ & & \\
\hline & Participation & $32.6( \pm 8.96)$ & $29.6( \pm 9.07)$ & $13.0( \pm 3.16)$ & $8.0( \pm 2.64)$ & $<0.001^{*}$ & $-0.818^{\# \#}$ \\
\hline & $\begin{array}{l}\text { Assistance } \\
\text { in Tasks }\end{array}$ & $134.0( \pm 28.59)$ & $142.6( \pm 14.85)$ & $84.25( \pm 30.85)$ & $43.33( \pm 2.30)$ & $<0.001^{* *}$ & $-0.721^{\# \#}$ \\
\hline \multirow{7}{*}{$\begin{array}{l}\text { Domains } \\
\text { of CPQoL- } \\
\text { Caregive }\end{array}$} & $\begin{array}{l}\text { Social Welfare } \\
\text { and Acceptance }\end{array}$ & $\begin{array}{c}89.5( \pm 6.5) \\
<0.001\end{array}$ & $\begin{array}{c}87.7( \pm 9.1) \\
<0.001\end{array}$ & $\begin{array}{c}90.8( \pm 6.8) \\
<0.001\end{array}$ & $\begin{array}{c}88.8( \pm 2.4) \\
<0.001\end{array}$ & 0.929 & 0.011 \\
\hline & $p-$ value $^{H+}$ & $\begin{array}{l}81.1( \pm 15.5) \\
<0.001\end{array}$ & $\begin{array}{c}81.4( \pm 13.6) \\
<0.001\end{array}$ & $\begin{array}{l}77.3( \pm 2.3) \\
<0.001\end{array}$ & $\begin{array}{l}46.8( \pm 10.8) \\
\quad<0.018\end{array}$ & $0.008^{1}$ & $-0.581^{\#}$ \\
\hline & Functionality & $\begin{array}{l}82.2( \pm 12.4) \\
\quad<0.001\end{array}$ & $\begin{array}{l}74.9( \pm 17.6) \\
\quad<0.001\end{array}$ & $\begin{array}{l}79.5( \pm 14.5) \\
\quad<0.002\end{array}$ & $\begin{array}{l}56.0( \pm 18.3) \\
\quad<0.034\end{array}$ & 0.173 & -0.363 \\
\hline & $p-$ value $^{\mathrm{H}}$ & $\begin{array}{c}93.2( \pm 9.1) \\
<0.001\end{array}$ & $\begin{array}{c}86.6( \pm 10.1) \\
\quad<0.001\end{array}$ & $\begin{aligned} 85.4( \pm 11.0) & <0.001\end{aligned}$ & $\begin{aligned} 78.4 & ( \pm 10.6) \\
< & 0.006\end{aligned}$ & 0.297 & $-0.513^{\#}$ \\
\hline & $\begin{array}{l}\text { Participation } \\
\text { and Physical } \\
\text { Health }\end{array}$ & $\begin{array}{l}68.7( \pm 14.8) \\
\quad<0.001\end{array}$ & $\begin{array}{l}74.1( \pm 21.0) \\
<0.001\end{array}$ & $\begin{array}{l}60.1( \pm 19.2) \\
\quad<0.008\end{array}$ & $\begin{array}{l}49.6( \pm 14.1) \\
\quad<0.026\end{array}$ & 0.303 & -0.372 \\
\hline & $p-$ value & $\begin{array}{c}42.8( \pm 30.2) \\
<0.034\end{array}$ & $\begin{array}{c}43.4( \pm 28.3) \\
<0.027\end{array}$ & $\begin{array}{l}35.9( \pm 19.5) \\
<0.035\end{array}$ & $\begin{array}{c}46.8( \pm 20.6) \\
<0.06\end{array}$ & 0.951 & -0.028 \\
\hline & $\begin{array}{c}\text { Emotional } \\
\text { Well-Being and } \\
\text { Self-Esteem }\end{array}$ & $\begin{array}{c}73.1( \pm 11.6) \\
<0.001\end{array}$ & $\begin{array}{l}66.2( \pm 25.9) \\
\quad<0.005\end{array}$ & $\begin{array}{l}64.8( \pm 21.5) \\
\quad<0.009\end{array}$ & $\begin{array}{l}37.5( \pm 6.2) \\
\quad<0.009\end{array}$ & 0.122 & $-0.536^{\#}$ \\
\hline
\end{tabular}

Caption: ${ }^{*}=p<0.05$ through Anova one-way with Tukey's post hoc, identifying differences between groups I-IV ( $\left.p=0.007\right)$, IV $(p=0.002)$, II-IV $(p=0.022)$ and II-V $(p=0.007){ }^{* *}=p<0.05$ through Mann-Whitney for non-normal distribution identifying difference between groups I-IV $(p=0.043)$, IV $(p=0.001)$, II-IV $(p=0.011)$ and II-V $(p=0.001) .{ }^{*}=p<0.05$ through Anova one-way with Tukey's post hoc, identifying differences between groups V-I $(p=0.01)$, V-II $(p=0.01)$ and V-IV $(p=0.029) .{ }^{*}=$ Significant Spearman correlation test for $p<0.05$ of moderate intensity. ${ }^{\# \#}=$ Spearman's correlation test significant for $p<0.01$ of strong intensity. ${ }^{*}=t$ test of a sample with significance level $p<0.05$. Source: Research Data, 2019.

Regarding QoL, also shown in Table 2, only the FUNC domain of CPQoL-Caregiver showed a difference between students with CP from GMFCS V with those from GMFCS I ( $p=0.01)$, II $(p=0.01)$ and IV $(p=0.029)$, with a moderate negative correlation for the FUNC domains $(p<0.05, \rho=-0.581)$, EWS $(p<0.05, \rho=-0.513)$ and FH $(p<0,05, \rho=-0.536)$.
All QoL domains showed intra-level differences in GMFCS, except for the Principal Idea Domain (PID) in GMFCS V students ( $p=0.06)$.

In the correlation of the total gross score of the GMFM-88 with the SFA and CPQoL-Caregiver domains, shown in Table 3 , there was a strong positive relationship between motor performance and 
participation ( $p=0.001, \rho=0.876)$ and assistance in tasks ( $p=0.001, \rho=0.843)$, as well as a moderate and positive correlation between the motor performance of students with CP and the FUNC domains $(p=0.046, \rho=0.490)$ and FH of the CPQoL-Caregiver $(p=0.028, \rho=0.531)$. Thus, these data indicated that students with CP assessed who had higher motor performance had better functionality, greater participation and school independence, and whose caregivers were healthier.

Table 3 - Correlation of the total gross score of the GMFM-88 with the SFA and CPQoL-Caregiver domains of students with Cerebral Palsy (CP) from Recife, Brazil, 2019

\begin{tabular}{|c|c|c|c|c|c|c|c|c|c|}
\hline & Participation & $\begin{array}{l}\text { Assistance } \\
\text { in Tasks }\end{array}$ & $\begin{array}{c}\text { Social } \\
\text { Welfare and } \\
\text { Acceptance }\end{array}$ & Functionality & $\begin{array}{c}\text { Participation } \\
\text { and Physical } \\
\text { Health }\end{array}$ & $\begin{array}{l}\text { Emotional } \\
\text { Well-Being } \\
\text { and Self- } \\
\text { Esteem }\end{array}$ & $\begin{array}{l}\text { Access to } \\
\text { Services }\end{array}$ & $\begin{array}{l}\text { Pain and } \\
\text { Impact of } \\
\text { Disability }\end{array}$ & $\begin{array}{l}\text { Family } \\
\text { Health }\end{array}$ \\
\hline $\begin{array}{l}\text { Correlation } \\
\text { coefficient }\end{array}$ & 0.876 & 0.843 & -0.054 & 0.49 & 0.285 & 0.374 & 0.351 & 0.138 & 0.531 \\
\hline$p$ value & 0.0001 & 0.0001 & 0.836 & 0.046 & 0.267 & 0.14 & 0.167 & 0.597 & 0.028 \\
\hline $\begin{array}{l}\text { Correlation } \\
\text { strength }\end{array}$ & Strong & Strong & - & Moderate & - & - & - & - & Strong \\
\hline
\end{tabular}

Source: Research Data, 2019.

\section{Discussion}

These findings suggest that, in the population studied, the higher the level of the GMFCS, the lower the participation and less independence in school activities, added to the QoL construct, with less functionality, less emotional well-being and self-esteem and less family health.

The use of assessments based on the ICF allows for a better interprofessional dialogue and direction of strategies for biopsychosocial health [2], so that the concepts of well-being, functionality and QoL are very close and need a good operational direction of the instruments to be used [23].

Understanding that functional aspects are only one of the determinants of QoL of students with CP [24], the use of instruments related to body structure and function and the levels of activity and participation of children, according to the ICF model, enabled a consistent assessment of students with CP. The FUNC domain of CPQoL-Caregiver considers issues related to the use of body parts and the skills of daily routine, comprising the scope of part I of the ICF, aspects complemented by part I of the SFA. Part II of the SFA and other CPQoL domains (EWS, SWA, PID, ACS and FH) include contextual factors of the ICF.

The findings point to less school participation and less independence in routine school activities among students with CP classified at higher levels of the GMFCS. These aspects were better understood with the finding of a strong negative relationship between motor performance and school outcomes. The negative relationship between the scores of the SFA parts and the GMFCS levels was seen in another study, indicating less school participation and independence in children with $\mathrm{CP}$ at higher levels of the GMFCS [5]. However, in this study, only one child was classified in GMFCS IV and there were no children classified in GMFCS $V$ and aspects related to contextual factors were not analyzed by the researchers.

National studies indicate the negative relationship between motor performance and school participation of children with CP [25], also with children with CP classified at levels I, II and III. These results reinforce nuances about the functionality of schoolchildren with CP classified in GMFCS IV and V, considering the development of inclusive strategies. For that, the school's partnership with other professional categories [26,27], structuring of collaborative consultancies [28], specific training on $\mathrm{CP}[29]$ and environmental readjustments $[25,30]$ can be suggested.

These strategies do not detract from the focus that should also be given to students with GMFCS CP I, II and III, which also deal with limitations in school activities and restrictions on participation [25].

Functional aspects also influenced the QoL of students with $\mathrm{CP}$, according to CPQoL-Caregiver. The FUNC domain in students with CP from GMFCS V showed a difference with GMFCS I, II and IV, with a moderate negative relationship. Recent studies with other instruments 
for assessing the QoL of children with CP also identified that children with $\mathrm{CP}$ with greater motor limitations and higher levels of GMFCS had lower scores in the domains of QoL related to functionality and social interaction [31,32].

It is important to consider that CPQoL is the first specific instrument to measure the QoL of children with $\mathrm{CP}$ in clinical practice, with excellent psychometric properties and adequate application time [33]. In studies using the two versions of $\mathrm{CPQOL}$, aimed at children and caregivers, a negative relationship was identified with GMFCS and FUNC [34,35], a finding that in the present study was complemented by the functional perspective in the school context.

Another finding of the present study concerns the negative influence of emotional aspects and self-esteem in schoolchildren with CP of higher levels of GMFCS, corroborating with studies that found lower scores in emotional aspects in children with $\mathrm{CP}$ of level $\mathrm{V}$ of GMFCS, using a general instrument of QoL [36], and greater influence of emotional well-being rather than physical well-being, as a predictive factor for QoL of children with $\mathrm{CP}$, also found in the scientific literature [37].

In contrast, studies that used CPQoL identified higher scores in the domains related to the emotional and social aspects of Finnish CP children, according to the parents' perception $[34,35]$. However, it is worth mentioning that part of the questions of the CPQoL-caregiver that make up this domain ("How do you thinkyour child feels about life in general?"; "How do you thinkyour child feels about himself?"; "How do you think your child feels about his future?") require a broad perception of the caregiver, enabling a bias to consider the caregiver's expectations more than the child itself.

Socioeconomic aspects are highlighted as factors that can influence QoL outcomes [38,39]. The social vulnerability of children with CP in public schools in Recife can be expressed by the municipal human development index of 0.772 , being located in the 216th position of the national ranking [40]. Such a context of vulnerability may be more prominent in children with $\mathrm{CP}$ with lower motor performance and classified in higher levels of GMFCS, which showed signs of greater caregiver burden [41]. Studies point out socioeconomic conditions, type of CP, caregiver's mental health as determinants of QoL for both [42], where health care and social support strategies are beneficial routes [43].

It is important to consider that the other EWS, PPH, PID and ACS domains of CPQoL-Caregiver did not show differences regarding the levels of GMFCS or relationships with the motor performance of the children assessed, demonstrating the subjective and individual perception of $\mathrm{QoL}$, dissociating the view of many professionals and researchers that QoL is determined only by functionality and suggesting the need for greater monitoring of the daily routine of children with $\mathrm{CP}$, as neuromotor impairment will not always correspond to low QoL [44]. As demonstrated in the present study, students with $\mathrm{CP}$ of the same functional level showed differences in the QoL domains of CPQoL-Caregiver, pointing out the subjectivity of the caregiver's perception in these aspects and the individuality of the children in the face of a small sample.

Based on the literature survey, to date, no studies using the associated GMFM-88, SFA and CPQoL have been found. The model followed by the present study facilitated the understanding of CP in the school context, considering tools that analyzed the relationships of body structure and function, levels of activity and participation and contextual factors of students with $\mathrm{CP}$, guaranteeing interprofessional dialogue and helping functional, inclusive and educational activities for students with CP.

This study had a clinical and epidemiological nature when evaluating, in line with the ICF, the functionality and QoL of students with CP, in view of the data collected from the municipal public school system. The small number of children with $\mathrm{CP}$ enrolled suggests the need for better planning of inclusive actions, and epidemiological studies that identify where these children are.

It is worth highlighting the difficulty encountered by the respondents regarding the development of the study before an atypical population, in a situation of vulnerability and heterogeneous in the multiple biopsychosocial aspects. In addition, the access difficulties faced by researchers both in the search for information and in direct contact with children, reinforce the need for rearrangements in the information and data control systems for this population.

\section{Conclusion}

Considering the ICF as a guiding tool and interprofessional dialogue, it was possible to detail the functionality of children with CP and its relationship with the health of the caregiver. New studies are suggested to assess other determinants of school participation and QoL of students with CP. 


\section{References}

1. Diniz D. O que é deficiência. São Paulo: Editora Brasiliense; 2007.

2. Organização Mundial da Saúde. Classificação Internacional de Funcionalidade, Incapacidade e Saúde. São Paulo: Centro Colaborador da Organização Mundial de Saúde para a Família das Classificações Internacionais; 2001.

3. Brasil, Ministério da Educação. Censo Escolar da Educação Básica: Notas estatísticas. Instituto Nacional de Estudos e Pesquisa (INEP). 2018.

4. Brasil. Movimento Todos Pela Educação. Observatório do Plano Nacional de Educação: indicadores [cited 2018 Dec 11]. Available from: https://tinyurl.com/ya29gvo4.

5. Rabinovich RV, Patel NV, Gates PE, Otsuka NY. The Relationship between the School Function Assessment (SFA) and the Gross Motor Function Classification System (GMFCS) in Ambulatory Patients with Cerebral Palsy. Bull Hosp Jt Dis. 2015;73(3):204-9.

6. Ghedini SLL, Mancini MC, Brito MB. Participação de alunos com deficiência. Rev Ter Ocup Univ Sao Paulo. 2010;21(1):1-9.

7. Abe PB, Araújo RCT. A participação escolar de alunos com deficiências na percepção dos professores. Rev Bras Educ Espec. 2010;16(2):283-96.

8. Silva DBR, Martinez CMS, Santos JLF. Participação de crianças com paralisia cerebral nos ambientes da escola. Rev Bras Educ Espec. 2012;18(1):33-52.

9. Souza ESD, Camargos ACR, Ávila NCI, Siqueira FMDS. Participação enecessidade de assistência na realização de tarefas escolares em crianças com paralisia cerebral. Fisioter Mov. 2011;24(3):409-17.

10. Abreu A, Alegrete N, Vieira I, Ana Abreu C. Avaliação de deformidades da coluna vertebral em adolescentes com paralisia cerebral. Rev Port Orto Traumat. 2014;22(3):370-8.

11. Hiratuka E, Matsukura TS, Pfeifer LI. Adaptação transcultural para o Brasil do sistema de classificação da função motora grossa (GMFCS). Bras Fisioter. 2010;14(6):537-44.

12. Rosenbaum PL, Palisano RJ, Bartlett DJ, Galuppi BE, Russell DJ. Development of the Gross Motor Function Classification System for cerebral palsy. Dev Med Child Neurol. 2008;50(4):249-53.
13. Palisano R, Rosenbaum P, Walter S, Russell D, Wood E, Galuppi B. Development and reliability of a system to classify gross motor function in children of cerebral palsy. Dev Med Child Neurol. 1997;39(4):214-23.

14. Russell DJ, Peter L, Rosenbaum PL, Wright M, Avery LM. Gross Motor Function Measure (GMFM-66 \& GMFM-88) User's Manual. London, UK: Mac Keith Press; 2002.

15. CosterWJ, Deeney T,Haltiwanger J,Haley S. School Function Assessment: user manual. San Antonio, Texas: Therapy Skill Builders; 1998.

16. Davies PL, Soon PL, Young M, Clausen-Yamaki A. Validity and reliability of the school function assessment in elementar school students with disabilities. Phys Occup Ther Pediatr. 2004; 24(3):23-43.

17. Waters E,Salmon L, Wake M. The child health questionnaire in Australia: reliability, validity and population means. Austr New Zeal J Pub Heal. 2000;24:207-10.

18. Waters E, Davis E, Mackinnon A, Boyd R, Lo SK, Wolfe R. Psychometric properties of the quality of life questionnaire for children with CP. Dev Med Child Neurol. 2007;49(1):49-55.

19. Bracialli LM, Bracialli AN, Sankako AN, Dechndt ML, Almeida V, Carvalho S. Quality of life questionnaire for children with cerebral palsy (CP QOL-CHILD): translation and cultural adaptation for Brazilian Portuguese Language. J Hum Gr Develop. 2013;23(2):1-10.

20. Cerebral Palsy Quality of Life Questionnaire for children (CP QOL-Child) manual. Melbourne, Australia: University of Melbourne; 2013.

21. Associação Brasileira de Empresas de Pesquisa - ABEP. Critérios de classificação econômica do Brasil. 2018 [cited 2018 Aug 1]. Available from: http://www.abep.org/ criterio-brasil.

22. Ferreira CG, Alexandre TS, Lemos ND. Fatores Associados à Qualidade de Vida de Cuidadores de Idosos em Assistência Domiciliária. Saude Soc. 2011;20(2):398-409.

23. Camargos ACR, Lacerda TTB, Barros TV, Silva GC, Parreiras JT, Vidal THJ. Relação entre independência funcional e qualidade de vida na paralisia cerebral. Fisioter Mov. 2017;25(1):83-92.

24. Davis E, Waters E, Mackinnon A, Reddihough D, Graham HK, Mehmet-Radji O, et al. Paediatric quality of life instruments: a review of the impact of the conceptual framework on outcomes. Dev Med Child Neurol. 2006;48(4):311-8. 
25. Furtado SRC, Sampaio RF, Kirkwood RN, Vaz DV, Mancini MC. Moderating effect of the environment in the relationship between mobility and school participation in children and adolescents with cerebral palsy. Braz J Phys Ther. 2015;19(4):311-9

26. Rézio GS, Formiga CKMR. Inclusão de crianças com paralisia cerebral em escola de ensino fundamental. Fisioter Pesqui. 2014;21(1):40-6.

27. Rosati AL, Fischer HZ. A inclusão de alunos com necessidades educacionais especiais na educação básica e a implementação de uma equipe multiprofissional na rede estadual de ensino. Rev Eletr Biol. 2014;7(3):241-51.

28. Tavares MTS, Teixeira RF, Bispo EPF. Inclusão de crianças com deficiência física na escola regular: desafios, estratégias e a importância da consultoria colaborativa. Rev Dial Persp Educ Esp. 2017;4(1):105-8

29. Melo FRLV,Pereira APM. Inclusão escolar do aluno com deficiência física: visão dos professores acerca da colaboração do fisioterapeuta. Rev Bras Educ Espec. 2013;19(1):93-106.

30. Cleary S, Taylor NT, Dodd KJ, Shields N. Barriers to and facilitators of physical activity for children with cerebral palsy in special education. Dev Med Child Neurol. 2019;55(6):509-19.

31. Dickinson HO, Parkinson KN, Ravens-Sieberer U, Schirripa G, Thyen U, Arnaud C, et al. Self-reported quality of life of 8-12-year-old children with cerebral palsy: a crosssectional European study. Lancet. 2007;369(9580):2171-8.

32. Badia M, Begoña Orgaz M, Gómez-Vela M, Verdugo MA, Ullán AM, Longo E. Do environmental barriers affect the parent-reported quality of life of children and adolescents with cerebral palsy? Res Develop Disab. 2016;49:312-21.

33. Gilson KM, Davis E, Reddihough D, Graham K, Waters E. Quality of life in children with cerebral palsy: implications for practice. J Child Neurol. 2014;29(8):1134-40

34. Boling S, Varho T, Kiviranta T, Haataja L. Quality of life of Finnish children with cerebral palsy. Disabil Rehabil. 2015;38(7):683-8
35. Boling S, Varho T, Mäenpää H, Forsten W, Autti-Rämö I, Haataja L. Measuring quality of life of Finnish children with cerebral palsy. J Ped Rehab Med. 2013;6(3):121-7.

36. Chen C, Sarah Chan P, Shen I, Wu C. Longitudinal changes in health-related quality of life in preschool children with cerebral palsy of different levels of motor severity. Res Develop Disab. 2017;61:11-18.

37. Kolman SE, Glanzman AM, Prosser L, Spiegel DA, Baldwin KD. Factors that Predict Overall Health and Quality of Life in Non-Ambulatory Individuals with Cerebral Palsy. Iowa Orthop J. 2018;38:147-52.

38. Power R, King C, Muhit M, Heanoy E, Galea C, Jones C, et al. Health-related quality of life of children and adolescents with cerebral palsy in low- and middle-income countries: a systematic review. Dev Med Child Neurol. 2018;60(5):469-79.

39. Badia M, Begoña Orgaz M, Gómez-Vela M, Verdugo MA, Ullán AM, Longo E. Do environmental barriers affect the parent-reported quality of life of children and adolescents with cerebral palsy? Res Develop Disab. 2016;49:312-321.

40. Instituto Brasileiro de Geografia e Estatística. Censo Demográfico 2010. Rio de Janeiro, RJ: IBGE; 2010.

41. Bailey DB, Ventura LO. The Likely Impact of Congenital Zika Syndrome on Families: Considerations for Family Supports and Services. Pediatrics. 2018;141:S180-7.

42. Tseng MH, Chen KL, Shieh JY, Lu L, Huang CY, Simeonsson RJ. Child characteristics, caregiver characteristics, and environmental factors affecting the quality of life of caregivers of children with cerebral palsy. Disabil Rehabil. 2016;38(24):2374-82.

43. Sheng N, Ma J, Ding W, Zhang Y. Effects of caregiver-involved interventions on the quality of life of children and adolescents with chronic conditions and their caregivers: a systematic review and meta-analysis. Qual Life Res. 2019;28(1):13-33.

44. Sanchez GC. Qualidade de vida e funcionalidade de alunos com paralisia cerebral matriculados na escola regular [dissertation]. São Carlos, SP: UFSCAR; 2018.

Received: 06/25/2019

Recebido: 25/06/2019

Approved: 10/31/2019

Aprovado: 31/10/201 